\title{
Rawls on Markets and Corporate Governance
}

\author{
Wayne Norman \\ Duke University
}

\begin{abstract}
Like most egalitarian political philosophers, John Rawls believes that a just society will rely on markets and business firms for much of its economic activity-despite acknowledging that market systems will tend to create very unequal distributions of goods, opportunities, power, and status. Rawls himself remains one of the few contemporary political philosophers to explore at any length the way an egalitarian theory of justice might deal with fundamental options in political economy. This article examines his arguments and conclusions on these topics. It argues that contemporary Rawlsians will reach different conclusions if they take more seriously than Rawls himself did: (1) the implications, for the political culture and the democratic regulatory state, of large firms competing in adversarial markets characterized by the inevitable "fact of market failure," and (2) the relevance of ownership and governance relationships involving different kinds of business firms. And with respect to the second point, Rawlsians and other egalitarians have much to learn from contemporary economic, legal, and sociological theories of the firm, and the role of these theories in the structure of and rationale for corporate law. This is the kind of social theory that Rawls believes is relevant to the justification and application of theories of justice, but he himself did not appeal to it in his writings on political economy. Contemporary egalitarians can and should appeal to it now, and in doing so correct errors and omissions in Rawls's analysis. But taking seriously the two points mentioned above will also force egalitarians who support efficient markets to face difficult dilemmas or compromises of their own.
\end{abstract}

KEY WORDS: Rawls, justice, markets, corporations, corporate governance, political economy

\section{INTRODUCTION}

$\mathrm{W}$ HAT IS THE ROLE, IF ANY, OF THE CORPORATION INA JUST SOCIETY? It is time that we push theorists of justice either to work out an answer to this question, or to demonstrate that theories of justice do not have to answer the question. This article offers suggestions and outlines challenges for theorists of justice ready to tackle the question head-on.

I begin with the following observations: (a) liberal egalitarians accept that a just society will need markets of some kind, along with large business firms competing in those markets; (b) liberal egalitarians have had very little to say about rules and regulations for such markets, about the governance and ownership 
arrangements for the firms, or about how institutionally to tame the well-known tendencies of markets and large business enterprises to promote unequal distributions of "benefits and burdens" and unequal relationships among individuals; and (c) there is an unfortunate dearth of discussion on the connections between theories of justice and democracy for "macro-level" systems and institutions (John Rawls's "basic structure"), "mid-level" (or "meso-level”) institutions such as firms, NGOs, or regulatory agencies, and "micro-level" ethical issues for individuals involved with these organizations. And this is highly problematic for theories at all three levels. ${ }^{1}$

Theorists of justice may reply that these are not their questions; or that these are not their questions yet-rather, they are details to be explored once we have a clearer understanding of the concept and demands of justice. Rawls, it must be said, did not think we could avoid these issues, even at the level of ideal theorizing. He explicitly endorses the idea that a just society will need markets and large business firms, and he provides details on the regulation of markets and firms, unlike most who would follow in his wake. But even he devotes only about 5 percent of the pages in two of his major works, A Theory of Justice (1971, as revised in 1999) and Justice as Fairness: A Restatement (2001b), that most directly address these issues. He believes that his two famous principles of justice are "standards by which to assess economic arrangements and policies, and their background institutions" (Rawls 1999, 228). Further, he contends that it is necessary to discuss "questions of political economy . . . to find out the practicable bearing of justice as fairness." 2 Put another way, given the demands of "reflective equilibrium," he recognizes that if we can't surmise the implications of a putative theory of justice for the design and justification of basic economic institutions, then we either don't really understand the theory, or it is not useful to us as a theory of justice. In just a few pages, Rawls illustrates how a citizen might ideally use his theory when "trying to organize his judgments concerning the justice of economic institutions" (Rawls 1999, 234). This article will discuss in some detail how Rawls himself thinks his theory should organize our judgments about the nature of the markets, market regulations, and the governance of firms. Rawls's approach to these questions of political economy and governance is still worth working through as a model for taking seriously the challenges of justifying market institutions with an egalitarian conception of justice. It is more detailed about these things than are most subsequent egalitarian theories of justice, and there is much to learn from both the details he discusses and those that he omits.

The articles in this special section on "Social Justice and the Corporation" share the three aforementioned observations and explicitly address these challenges. Abraham Singer's article argues that we should be skeptical that anything like a Rawlsian theory of justice can help us to answer either fundamental or practical questions about corporate governance - and, furthermore, that this should be of more concern for Rawlsians than for business ethicists. Pierre-Yves Néron considers and rejects in his article a number of excuses contemporary egalitarian theorists (including Rawlsians) have offered for ignoring corporate governance and organizational structures. He remains optimistic, though, that the revival of interest among 
some leading egalitarian theorists in the justice of relationships, and not merely of distributions, may draw corporate and organizational governance issues closer to the center of discussions about economic and social justice. In this article, I will attempt to show why questions of governance and the ownership of business enterprises are crucial to addressing long-standing questions of political economyabout choosing from among capitalism, socialism, and "property-owning democracy," for example. Put more bluntly, I will advance the notion that political philosophers cannot possibly evaluate the justice of political-economic systems without finally opening the "black box" of the business firm, as practitioners in the fields of economics and the social sciences have done for decades. Using Rawls's discussions of justice and political economy, I will illustrate the relevance of corporate governance and provide cautionary tales about the significant challenges egalitarian theorists of justice will face if they are to take the modern corporation, and its role in society, seriously.

\section{JUST CORPORATE GOVERNANCE? THE LEGACY OF RAWLS IN BUSINESS ETHICS}

Despite increased activity in this domain of late, Singer (2015) notes that "the cross-pollination of ideas between business ethics and political theory has been largely unidirectional: political theorists have shown little interest in business ethics or corporate governance." 3 With this special section coinciding with the 25th anniversary of the launch of Business Ethics Quarterly, we take stock of the use leading scholars in business ethics have tried to make of the dominant egalitarian theorist of justice, John Rawls, over this same quarter century. Well-regarded works on the philosophical foundations of normative business ethics are likely overrepresented in $B E Q$. We find Rawls cited or mentioned in 208 of the 1150 articles and book reviews published in BEQ up to the end of 2014. Only Aristotle (218) and two contemporary deans of business ethics (Thomas Donaldson, 281 times, and R. Edward Freeman, 270 times) have been cited more often in the journal. ${ }^{4}$ But a closer look at the actual discussion of Rawls's work reveals a less-than-thorough or systematic attempt among scholars of business ethics to explore the grounding of their mostly mid- and micro-level normative theories in something like Rawlsian principles for the basic structure of society. Of the 174 articles (including review articles, but not book reviews) citing Rawls, only 14 mention him in the title or abstract, and most of those do not actually discuss the parts of Rawls's works that are directly concerned with political economy and the kinds of ownership and governance arrangements that would be permitted in a just society. The legacy of Rawls in $B E Q$ is, in fact, much the same as it is across moral and political philosophy. There are many dozens of references in $B E Q$ to Rawls's most general methodological concepts: the original position and veil of ignorance, the idea of a social-contract normative theory, the notion of reflective equilibrium, and more recently the idea of "reasonable pluralism" as a norm for diverse societies. A little more than a dozen of the articles citing Rawls are primarily about international justice, with nine of them citing his book The Law of Peoples (2001a). There are just seven 
citations in $B E Q$ to the book that contains Rawls's last and most detailed discussion of political economy and governance, Justice as Fairness: A Restatement (2001b), which appeared about halfway through $B E Q$ 's first quarter-century.

In the end, for all of the "reaching out" by business ethics scholars to the most influential theorist of social and economic justice during the lifetime of this journal, we can actually count on one hand the articles that engage at length with Rawls's thoughts directly on the economic institutions mentioned in observations (a) and (b) in the first paragraph of this article. Certainly, other articles in $B E Q$ have taken up these concerns by reaching out to other traditions of theorizing about justice and democracy (e.g., some connecting recently to abstract Habermasian conceptions of deliberative democracy, and others, as implied by note 4 above, to nonegalitarian theorists of justice such as those of Nozick and Hayek).

These discussions in business ethics have typically been framed by asking whether a normative theory or approach could be "borrowed" from a political philosopher, such as Rawls, and then "applied," more or less directly, to managerial or governance questions within the world of business. Quite likely the most influential article posing a question like this in $B E Q$ is Robert Phillips and Joshua Margolis's "Toward an Ethics of Organizations" (1999), which makes a strong case for the autonomy of "mid-level" organizational ethics from both macro-level theories of justice, like that of Rawls, and micro-level theories of ethics for individuals. That article prompted lengthy replies in BEQ by Edwin Hartman (2001) and Jeffrey Moriarty (2005). And this debate, along with critiques of overly direct applications of Rawlsian contractarian arguments to ethical decision making in business, is taken up in this special section by Singer (see also, e.g., James Child and Alexei Marcoux's "Freeman and Evan: Stakeholder Theory in the Original Position," BEQ, 1999, and Richard Toenjes's "Why Be Moral in Business? A Rawlsian Approach to Moral Motivation," BEQ, 2002).

Like Phillips and Margolis, Singer is arguing for what he calls a "null-hypothesis" when it comes to the relevance of Rawls's theory to corporate governance. But all three articles in this special section can be seen as reversing the framing of the question about the possible link between a theory of justice and theories of corporate governance. Rather than asking the more familiar question about the "applicability" of Rawlsian principles in an organizational and governance context, the three articles in this issue are asking, in effect, whether sophisticated and robust theories of corporate governance-either already existing or potentially reformed-could be "handled" or "accepted" by mainstream egalitarian theories of justice. The reversed framing is subtle, and it allows for continued engagement with existing debates. But it also deals head-on with a serious potential obstacle to connecting these two very different kinds of normative theories, which have been developed largely in isolation from each other. It is possible that, in ignoring the corporation, political philosophers have created normative theories that are now, in some sense, incapable of justifying or legitimizing viable and efficient business firms, capitalist or otherwise. So, if Singer's null-hypothesis is correct, he is not simply interpreting this limitation of Rawlsian theory as a green light for theorists of corporate governance and business ethics to get on with other 
kinds of normative theorizing for mid-level organizations like business firms (which is what Phillips and Margolis do in the domestics sphere, and Arnold [2013] does in the global sphere with his critique of the relevance of Rawls's theory of global justice for international business ethics). Singer, Néron, and I all take seriously the possibility that theories of justice may be seriously flawed if they cannot show, as Rawls himself clearly believed they must, how markets of some kind, incorporating large business organizations, can be designed and regulated within a just society (not to mention a just global economy).

This concern - that contemporary egalitarian theories of justice and democracy may not be able to ground viable models of political economy and corporate governanceseems to have emerged spontaneously in a number of very different research projects over the past five years. We see it in the searching critiques of four recent articles in $B E Q$; collectively, these articles discuss the role of corporate governance in Rawls's theory in greater detail than have all of the articles citing Rawls over the first two decades of $B E Q$ 's publication combined. The four articles I refer to were published in 2012 and 2013 and include Denis Arnold's Society for Business Ethics Presidential Address, "Global Justice and International Business" (2013); articles by Glen Whelan (2012) and by Jukka Mäkinen and Arno Kourula (2012) on the foundations of so-called political CSR; and Sandrine Blanc and Ismael Al-Amoudi's "Corporate Institutions in a Weakened Welfare State: A Rawlsian Perspective" (2013). Beyond the pages of $B E Q$, in two recent books with very different conclusions (O'Neill and Williamson 2012; Heath 2014), we see a redoubling of efforts to demonstrate the suitability of something like a Rawlsian approach to justice for the hard choices of institutional design in political economy and corporate governance.

Rawls famously rejected both capitalism and state socialism in favor of some kind of market socialism or so-called "property-owning democracy," the latter probably being his preferred option. But until a sprawling and multidisciplinary collection of chapters in the volume Property-Owning Democracy: Rawls and Beyond (2012), edited by Martin O'Neill and Thad Williamson, there was almost nothing written in the Rawlsian tradition on the nature of this corporate governance regime. ${ }^{5}$ Heath takes a different approach, one that potentially reconciles Rawlsians to a regulated capitalist system of markets and corporations. His Morality, Competition, and the Firm: The Market Failures Approach to Business Ethics (2014) extends the theory he first outlined in "Business Ethics without Stakeholders" (2006a). The argument in the earlier article is largely directed toward economists and others who justify markets on the grounds of efficiency. It made a compelling case that, in the face of market failures that cannot be "corrected" with regulation, the same justification for markets will also justify a wide range of "beyond-compliance" ethical obligations for businesses and their agents. It amounted to "business ethics without stakeholders," because Heath argued that it provided a more convincing rationale for these norms than so-called "stakeholder theory" does.

The more fully developed version of this argument in Heath's recent book also addresses an audience of egalitarian, especially Rawlsian, liberals. Heath's provocative suggestion - a game changer if he's right - is that egalitarian theories of justice can accommodate the rough-and-tumble world of competitive markets 
and business firms if they recognize Paretian efficiency as a "third-best" ideal principle of justice. The move is analogous to the one Heath interprets Rawls as making when he opts for the "difference principle" over a purely egalitarian principle as a "second-best" principle for the just distribution of primary goods. For Heath, an ideal moral theory of the "second best" follows the basic rules worked out by economists when "first-best" market conditions are absent. What Richard Lipsey and Kelvin Lancaster demonstrated in their famous article "The General Theory of the Second Best" (1956), as Heath summarizes it, is that "if the conditions required for perfect competition cannot be satisfied (for some 'merely empirical' reasons), then satisfying them as much as possible will not ... produce an outcome that is as close as possible to the Pareto-optimum" (Heath 2014, 176). Heath believes that normative theorists also have to move to second-best (or third-best) theories when our understanding of, say, human psychology shows that attempting to institutionalize a first-best (or second-best) normative principle would be self-defeating. He further argues that the "compromise that is the heart of capitalism" is something egalitarians have to accept as a third-best ideal theory of justice.

We could choose to organize the economy as a system of direct cooperation (through some sort of central planning mechanism), the problem is that without prices, it is incredibly difficult to decide how to allocate goods, resources, and labor in such a way as to best satisfy our needs. By allowing free exchange and competition to develop, it becomes possible to achieve significant efficiency gains. The downside is that, in so doing, we relinquish direct control over the system of allocation, and so are unable to ensure that it satisfies the norm of equality. This constitutes, I have suggested, the adoption of a third-best framework, wherein we refrain from applying the egalitarian norms that we would normally apply to assess cooperative interactions. We try to get market-clearing prices because of their efficiency-promoting qualities, while acknowledging that the distributive consequences of this will be pretty much arbitrary from the standpoint of justice. To the extent that we do bring in considerations of equality and distributive justice, these take the form of outside boundaries or constraints, such as the minimum wage, or certain restrictions on "unconscionable" contracts. (Heath 2014, 191)

Heath goes on to argue that once they reconcile themselves to Pareto efficiency as the third-best principle of justice, egalitarians will still find plenty of resources to be able to condemn socially irresponsible corporate practices and to justify the regulation of those practices. Both Singer and Néron discuss this argument in detail, so I needn't pursue it here. Heath's medicine will taste like a very bitter pill for egalitarians. My aim in the remainder of this article is to explain why the "disease" the pill is trying to cure is much more serious than most egalitarian political philosophers seem to realize, given the presumptions stated at the outset: namely, (a) that these philosophers would like a just society to benefit from the efficiency of markets and modern firms, despite (b) persistent worries about the well-known tendency of markets toward inequality, and (c) the fact that they have generally neglected insights from the social sciences about the mid-level institutions and organizations between the state and the individual that are crucial to an understanding of the design or regulation of markets and firms. 


\section{BEYOND "THE MARKET”}

I will not be defending this broad generalization about the conundrum of markets and firms for most egalitarian political philosophers here (I have done so elsewhere in Heath, Moriarty, and Norman 2010), as both Singer and Néron do so in their contributions to this issue. It is fairly safe to say that this neglect has not been obvious to most political philosophers: it is rare even in book-length treatises on justice to find political philosophers explaining or justifying such lapses.

A political philosopher might retort that markets have been an important part of discussions of political philosophy for the past forty years. The difficulty with this response is that vague discussions of "the market" by political philosophers conceal three vast domains, each of which is a major topic of research in law and the social sciences. First, given the values, relationships, and principles that egalitarians take seriously, a serious discussion of political economy must get beyond general references to "the market" and acknowledge important distinctions; clearly, markets for commodities, futures, currency, intellectual property, labor, insurance, equity, corporate control, political access, consumer goods, sexual services, carbon permits, green energy, cocaine, firearms, newspapers, telecommunications, internet-service provision, credit, pay-day loans, and organs from living sellers are not all the same kind of thing. ${ }^{6}$

Second, a serious discussion of the limits or justification of any particular market (or of behavior within that market) will almost always require an analysis of the design and justification of the regulations for that market. Administrative regulatory agencies, rather than legislators or citizens, are now responsible for the vast majority of lawmaking in "market democracies." And yet, the sort of democratic theorizing carried out in recent decades by liberal political philosophers has had very little to say about how elected officials or citizens should best direct, oversee, or audit the regulatory agencies responsible for curtailing the unjust and inefficient exploitation of market failures in business. ${ }^{8}$ So I submit that one cannot have a particularly useful discussion about "the market" in a just society without dealing with significant distinctions between different kinds of markets, along with questions of how particular markets ought to be designed and regulated. For the most part, however, I shall set these two issues aside.

The main focus, both in this article and in this special section, is with the third significant element of "the market" that has been strangely overlooked in philosophical theories of justice: the fact that the primary "agents" in contemporary markets are very large business firms - in particular, the limited-liability public corporation with widely dispersed ownership, which has been the real engine of capitalism since the early-to-middle decades of the twentieth century in the United States and Europe.

Corporations are not markets. They are typically hierarchical command-andcontrol organizations that are simultaneously engaging in market transactions for a variety of goods, services, labor, credit, debt, insurance, and so on. Within a corporation, some employees have the authority to tell other employees and contract workers what to do (within limits specified by contracts and by various 
bodies of law for employment, health and safety, civil rights, and so on). And the most senior manager reports to a board elected by stockholders. Other types of business firms (those which are not public corporations, e.g., privately held firms, cooperatives, not-for-profits, state-owned firms) can be very similar in all respects, except that the board is elected or appointed by some other constituency. Theories of governance focus-first and foremost, but not exclusively-on the nature of ownership, the rules for choosing a board, the obligations of both the board and the board members, and their complex multifaceted relationship with the senior executives. When economists and corporate lawyers talk about opening the "black box" of the firm, these are the kinds of roles and relationships they are trying to understand. ${ }^{9}$

Political philosophers recognize the tremendous power that actual corporations have in our economies, cultures, and political systems; indeed, egalitarians and libertarians alike are concerned about this. But even in philosophical theories of justice that see the importance of understanding the "logic" and efficiency properties of markets, the corporation usually remains the "black box" it was in the early decades of microeconomics and welfare economics, or in the first chapters of an Economics 101 textbook, moving from Robinson Crusoe-like exchanges among individuals to simple models involving profit-maximizing firms and utilitymaximizing households.

Rawls seems generally to assume that we can think through most questions of political economy without opening the "black box" of the firm. Sometimes, this is because he draws on models from economics that treat firms in this way. "Whatever the internal nature of firms," he remarks, in one of the few places he explicitly broaches the issue of governance in A Theory of Justice, "whether they are privately or state owned, or whether they are run by entrepreneurs or by managers elected by workers, they take the prices of outputs and inputs as given and draw up their plans accordingly" (Rawls 1999, 241). Note, however, that this is not an empirical claim about firms; rather, it is a tautology within a simplified economic model that defines a firm as a business unit that transforms inputs into outputs within perfectly competitive markets for both the inputs and the outputs. As an empirical claim, however, this would be false in almost all actual markets, which, as Rawls himself clearly recognizes, are not perfectly competitive. Questions about the corporate form, along with the governance structures and enabling statutes for other kinds of business firms, arise precisely because it is not the case that the "internal nature" of different kinds of firms is irrelevant to how efficiently they can operate, to how innovative they are at product or process design, to the prices at which they are able to sell their products, or to the kinds and "quality" of relationships they structure for the individuals "inside" the firm. ${ }^{10}$ Anything that makes a firm more efficient than its competitors-from its governance structure or technological innovation, to its possessing a unique ability to exploit a market failure - can enable it to make a profit while offering its goods or services at a lower price than its market competitors can sustain.

In another passage that refers to an important governance element (the question of ownership), Rawls says that it is "evident" that 
there is no essential tie between the use of free markets and private ownership of the instruments of production. The idea that competitive prices under normal conditions are just or fair goes back at least to medieval times. While the notion that a market economy is in some sense the best scheme has been more carefully studied by so-called bourgeois economists, this connection is a historical contingency in that, theoretically at least, a socialist regime can avail itself of the advantages of this system. One of these advantages is efficiency. (Rawls 1999, 239-40, my italics)

It is hard to know what to make of this claim, in part because of the vagueness of the terms I have italicized. It is certainly possible to have markets in an economic system where all firms are owned by the state. It is not clear that these would qualify as free markets, given the bureaucratic and legal barriers to entry, among other things. But perhaps it's never clear how much regulation in a given market, even in a capitalist system, is consistent with calling the market "free." Nor is it clear what it means to say that, "theoretically," a socialist regime can set up markets with only state-owned firms that can be efficient. Surely, what will matter at some point when we are trying to evaluate whether some given kind of economic system is to be preferred by a conception of justice is just how efficient or inefficient it is, among other things. And one of the things that will affect the level of efficiency in a market is the way it tries to solve governance issues - in particular, the big one involving the ability to control senior managers who enjoy information asymmetries over those who must oversee and direct them, and who have effective control over the assets of the firm which they can exercise effectively, or lazily, or amateurishly, or corruptly. A market full of badly governed firms may be "theoretically" efficient, but not in the way that matters for social welfare or social justice. This, in a nutshell, is what it means to say "governance matters." In particular, as we will discuss later, multidisciplinary research on theories of the firm over the past few decades gives ample evidence that some governance and ownership regimes are much more effective than others in given market situations. ${ }^{11}$

So, if a theory of justice has to be able to say something about justification and limits of markets in a just society, then it also has to say something about the justification of permitting or forbidding the formation of different kinds of business firms (that is, according to their ownership and governance structures). In particular, it has to consider the grounding, and ultimately the details, for the bodies of law that structure the charters for different kinds of business firms, especially the law of corporations, along with similar statutes for other kinds of business organizations, among them cooperatives, not-for-profit businesses, partnerships, sole proprietorships, social enterprises, and state-owned enterprises. (See the opening section of Singer's article in this issue for a sample list of more specific " 'big' and 'important' normative questions of business ethics or corporate governance . . . with obviously important social and political implications.")

The brief quote from Rawls (above) about all firms being price-takers for inputs and outputs involves a typical economist's idealization. But it is not the kind of idealization that we can incorporate into the kind of ideal theorizing about justice that Rawls wants to carry out in his discussion of political economy. Again, the 
economist's claim is not about real businesses: rather, it is a tautology within an economic model of perfect competition. Rawls knows that "of course, the requisite conditions [for perfect competition, and thus maximal efficiency, in the theory of general equilibrium] are highly special ones and they are seldom if ever fully satisfied in the real world" (Rawls 1999, 240). He argues that markets will be used in a just society for the exchange of many kinds of goods and services primarily because of their efficiency properties, and also because they are "consistent with equal liberties and fair equality of opportunity" and with the "free choice of careers and occupations" (Rawls 1999, 240-41). He would have governments regulate markets to correct for the inevitable market failures discussed in economics textbooks of his day: "monopolistic restrictions, lack of information, external economies and diseconomies," as well as negative externalities, and the fact that "the market fails altogether in the case of public goods" (Rawls 1999, 240). This sounds like the standard case, both for having free markets and for regulating them, that one finds in pro-capitalist defenses of the market system. What is striking, however, is that Rawls explicitly rejects the possibility of capitalism-even capitalism with a generous welfare state-in a just society. We will look at these arguments against capitalism later, but at this point it is worth highlighting the role that seems to be played by the two passages from Rawls that we have been discussing in this section. They appear to be his reasons for assuming that variations in ownership and governance structures for various kinds of firms are not especially relevant to how efficiently a given firm will perform its role of transforming inputs into outputs. If this were the case, then we wouldn't have to give up the advantages of market mechanisms if we decided for other justice-based reasons that, say, all firms should be owned by the state or controlled by their workers. For Rawls, the key is that market forces - not central government planners — should be used to determine prices and the allocation of resources to produce what consumers prefer. Again, that is a spectacularly radical conclusion to draw about real economic arrangements in a just society, considering the fact that these tautologies would be false if interpreted as empirical claims about any post-industrial economy we could now realistically imagine (and citizens applying his principles are supposed to imagine realistic options).

Although parties in the original position, the constitutional convention, and the legislative stages of Rawls's ideal theorizing are allowed to appeal to knowledge about human behavior, drawing on stylized definitions and tautologies from abstract economic theories in this way is inappropriate. ${ }^{12}$ We need only refer again to Lipsey and Lancaster's article titled "The General Theory of the Second Best" (1956), which warns us that such theories will mislead us in the real world, where the conditions of perfect competition are not satisfied. We cannot assume that the closer we come to approximating the conditions of a perfectly competitive market, the closer we will get to achieving the efficiency it promises. Of course, Rawls's parties can make use of very robust empirical models from other parts of economics, organizational theory, and even direct studies of governance practices. And if they do, they will surely reject his assumption that the efficiency properties of markets are not dependent on the structure of ownership and governance arrangements for the firms that are competing in those markets. 
Let us return to the problem of market failures, which are a critical issue for any justification of markets. Rawls rightly notes that "when markets are truly competitive, firms do not engage in price wars or other contests for market power" (Rawls 1999, 241). And also, as we have seen, he realizes that markets are rarely if ever truly competitive in the real world. It would seem most reasonable for a Rawlsian to simply assume that market failures are as much a fact of life in a post-industrial, post-commodity, high-tech consumer economy as value pluralism is in an open democratic society. You cannot have a perfectly competitive market for iPhones, or even for smartphones. As we know, the "fact of pluralism" radically transformed the aims, scope, and principles of a theory of justice for Rawls. ${ }^{13}$ We might expect that the "fact of market failures" should do the same for a liberal-egalitarian's political economy - especially given our experience after several decades of creating regulatory agencies, which, at the very least, makes us less optimistic that regulations or "compensating adjustments" by a Rawlsian "allocative branch" (Rawls 1999, 244) will easily correct for them.

Why does this all matter for theories of justice? And, in particular, why does it reinforce the case (pursued in different ways by the three articles in this special section) for taking corporate governance more seriously when grounding and applying theories of justice? It is not so much that market failures (such as market power, negative externalities, or information asymmetries) wipe out efficiency in modern markets. That is a complicated story: market failures can often facilitate efficiency and innovation (think of economies of scale, which can't arise in a perfectly competitive market), and sometimes we create a market failure (e.g., with intellectual property law) to help overcome another problem (the disincentive to produce public goods). In any case, it is surely no coincidence that the decades following the emergence and dominance of the widely held public corporation have also been the decades with the most staggering creation of economic value the world has ever seen. (And this correlation looks like even less of a coincidence when we see a similar sequence in economies that have developed more recently.) The problem with the "fact of market failures" is that market failures, in theory and in practice, are the primary source of profit for firms. The notion that firms will "not engage in price wars or other contests for market power" is irrelevant to our thinking about justice and real-world markets. We must assume, on the basis of the sort of knowledge of human behavior that Rawls permits even within ideal theorizing, that profit-seeking firms definitely will engage in contests for market power. When that would be futile for some firms, we can assume that they will engage in tactics and strategies to exploit any market failure (or "competitive advantage") available by, say, externalizing the cost of pollution, consumer or worker safety, or systemic risk (as large financial institutions do when they are convinced they are too big to be allowed to fail); or duping employees, customers, investors, or tax authorities through the exploitation of information asymmetries. We can also assume that they will undertake legally available means to influence political, administrative, and judicial attempts to regulate the exploitation of profitable market failures. They will even use similar means to get governments to create or strengthen regulations when they believe that this will give them a competitive advantage. 
What is the upshot of all of this? For one thing, once again, governance structures matter. Not all types of business firms will, in a given situation, be incentivized to the same degree to increase their profits through business strategies that exploit various market failures, or through political strategies that create and sustain profitable market failures through dubious rent-seeking interactions with politicians and government regulators. We would certainly expect public corporations to have very high incentives, and often more readily available resources, to undertake such strategies. Why? Well, we have to open up the "black box" to see. The senior managers might not want to pursue such a strategy, but the corporate law and the governance structure of a public corporation can make them do it anyway. Take, for example, the following case. A corporation is legally permitted, given existing regulations, to pollute their local water supply. It would be very expensive to treat their waste products and reduce the toxic emissions below the level required by law, so undertaking such a "beyond-compliance" policy would either lower their profit margins, or make them raise their prices, which would cost them market share, revenue, and profits. Let's assume, as will often be the case, that there is no compensating payoff for their brand if they are seen to be a socially responsible corporation. Other things being equal, not exploiting this legally available externality would lower share prices, and the current board of directors might interpret this as an indication the CEO was underperforming. And if they did nothing about it, the corporation could be taken over by investors who would hire a new CEO to do just that. So, with this system of governance, even business leaders who don't want to do something harmful and unjust will have strong incentives to do those things anyway.

But imagine instead the firm in question has another governance structure: it is not a public corporation but a supplier-owned cooperative, and the suppliers live near the company's plant that has been causing the pollution. Imagine also that the pollution doesn't affect the suppliers' ability to supply their product; it simply lowers their quality of life, from their perspective, as people who live near the plant. The managers of this firm may well get the green light from the board, which is made up of representatives of the suppliers, to install the expensive pollution controls. This would have the same foreseeable result that profits would be lower. But the owners could decide that they are all better off with less surplus revenue and a safer or more pleasant local environment. And nobody else could swoop in and take the firm from them in order to undo the policy.

This is obviously a simple and very particular case study. It is not meant to give any general reasons to prefer supplier-owned co-ops to public corporations. ${ }^{14}$ All that particular stories like this show is why it is simply not true that, "whatever the nature of the firm," it will behave in similar ways to transform inputs into outputs-especially given profitable opportunities arising from market failures and rent-seeking that can be exploited in different ways by firms with different governance structures. ${ }^{15}$ From this it would seem to follow that a theory of justice can say little about the economy or the efficiency of markets without considering theories of organizational form and governance. 


\section{DELIBERATELY ADVERSARIAL INSTITUTIONS IN A JUST SOCIETY}

Another way of drawing out the implications of the "fact of market failure" is that it should force any theorists of justice who makes room for markets to take seriously the many faces of highly competitive, even adversarial, markets. Recall Rawls's belief that many decisions about a market system, including important questions about who should own and who should control the means of production, can be decided at the level of ideal theory. Decisions about the institutions and property rights for the market system come up at the second and third stages of the so-called "four-stage sequence," where we "take up the perspective of the constitutional convention or the legislative stage and ascertain how the principles of justice apply" (Rawls 1999, 229). ${ }^{16}$

Rawls's project, and those of most liberal-egalitarian theorists who expect their principles to be relevant for institutional design, accepts the challenge presented by Jean-Jacques Rousseau in the opening lines of his Social Contract: Rousseau announces that he would like to find "any legitimate and sure principle of government, taking men as they are and laws as they might be" (1968, 49). Broadly speaking, there are two ways to envisage just institutions for a society in which we do not assume that people, as they "are," will be particularly altruistic. First, we can hope that there is at least a class of people (Plato's guardians, Jeremy Bentham's bureaucrats, Nikita Khrushchev's technocrats) who will act nobly and, through the machinery of government, provide the kinds of services and benefits that justice requires. Or we can try to design institutions in which "mutually disinterested" citizens, to use Rawls's term, pursue their own interests in a competitive context that yields net benefits for the greater good of society. In short, you can use the visible hand of an honorable elite, or the invisible hand of a well-designed competition. (Of course, the distinction is overdrawn; both types of institutions will assume some non-altruistic behavior, but they will also demand ethical behavior on the part of both administrators and citizens.) These latter kinds of competitive institutions are "deliberately adversarial." We invite participants within them to compete in contests where there are winners and losers, and where participants are excused from some ordinary duties of reciprocity or cooperation.

Several systems of adversarial institutions are now assumed to be irreplaceable fixtures in modern democratic states, most notably in electoral systems for legislators (but not necessarily for judges); in markets for goods, services, labor, capital, and insurance (but not necessarily for health insurance); and in criminal law. Deliberately adversarial institutions have the structure of professional sports leagues: competitors need not be especially motivated to please "the public" when they compete on a specific terrain to win; there are rules in place that are designed to make this competition benefit the public outside the competition; ${ }^{17}$ these rules are monitored by "referees," who enforce sanctions for discovered violations; and the rules and sanctions, as well as the "prizes" for the winning participants, are subject to continual revision by the authorities. Rawls actually employs a sporting analogy to explain his basic point of adjusting the background conditions of justice while letting the teams otherwise play to win: he cites favorably the use of a sequential draft for all incoming players before each new season in big American 
professional sports leagues, with the "worst-off" teams getting the first chance to select the best rookies $(2001 \mathrm{~b}, 50)$.

I noted at the outset that all three of the articles in this special section underscore the dearth of attention in post-Rawlsian political philosophy to mid-level (or meso-level) institutions. Political philosophers continue, by and large, to theorize for a world with individuals, social or cultural groups, and state institutions. They routinely write about democracy without paying much attention to political parties, ${ }^{18}$ and they can write about markets without paying much attention to corporations, the professions, or regulatory agencies. This neglect of mid-level institutions is most glaring in systems where such institutions are engaged in competitive rather than cooperative or administered activities. When the adversarial nature of, say, democratic politics, law, or business is taken into account, it is usually with lament-as if society would be better off in each of these realms if we aimed instead for direct cooperation. There are many obvious challenges in the design of deliberately adversarial institutions for a just society.

- There will almost always be potentially winning strategies for individual players (say, a corporation or a political party) that will not benefit third parties or the public outside the competition.

- When the stakes are high enough, even non-greedy, "mutually disinterested" players will look for such strategies and be tempted to use them if they can get away with them. (Cognitive biases and rationalizations will enable even high-minded players to succumb to such temptations.)

- It is rarely possible to design a set of rules and regulations for a complex competition - at the level of a market, an electoral system, or even a professional sporting event - that cannot be gamed or subverted in some way.

- It is rarely possible to discover, or to adequately punish, all of the clear transgressions of the rules.

- As Heath puts it, "In a non-adversarial context, the fact that one person acts unethically does not in itself create any additional pressure on others to do so.... In a competition, however, the fact that one person is deriving an advantage from unethical conduct necessarily generates a disadvantage for everyone else, and therefore creates pressure for everyone to follow suit. Once one athlete starts taking steroids [for example], it is very difficult for the others to stand by and do nothing. Acting ethically, in this context, means losing the competition" (Heath 2014, 112).

- Even when all rules are complied with in letter and spirit, these are "imperfect" procedures. The superior team may (perhaps because of very bad luck) lose the championship game; the jury may be swayed by a brilliant prosecutor to convict an innocent person; the voters may elect an incompetent and corrupt government.

Yet, despite all of these common shortcomings, we tend to rely on deliberately adversarial institutions in the realms mentioned because, to paraphrase Winston Churchill, they are not as unreliable as their non-adversarial alternatives (planned economies, monarchies, inquisitions, watching athletes practicing and posing, and so on) ${ }^{19}$ 
The basic question I want to ask is, how do we design and justify regulations and governance statutes for the firms within adversarial markets? Or, more to the point, how abstractly or "ideally" can we do this? How much of the design and justification can usefully be done initially at the very abstract level of ideal theory that Rawls aims for in his theory of justice? These are deep and largely unexplored questions. ${ }^{20}$ Although Rawls and other contemporary liberal-egalitarian theorists want to make room for deliberately adversarial markets, it is not at all clear that they have faced the challenge of reconciling the permissible, strategic, self-seeking behavior for agents within these institutions with otherwise broad expectations that citizens should act at all times from a sense of justice. Consider a few examples of tensions between the norms of competitive markets and those of liberal citizenship.

i. Rawls's quaint Economics 101 (circa Alfred Marshall) descriptions of markets and the price system are usually, as we have seen, set within the imaginary world of perfect competition, with managers bureaucratically using capital and labor to transform inputs into outputs as price-takers. He gives little indication that he envisages how ferocious the drive for greater efficiency, productivity, rents, and profits can be across the many overlapping and tightly competitive markets for goods, services, capital, and insurance. In places, he contemplates, in nineteenth-century terms, the possible viability of a "steady state" economy in which there is little need for growth, innovation, or competition.

ii. As noted earlier, Rawls recognizes that actual markets for most goods and services diverge from the standards of perfectly competitive ideal markets; thus, he explicitly envisages a role for government regulations to deal with market failures like negative externalities, information asymmetries, market power, and the disincentive to produce public goods. Rawls's own life corresponds to the golden age of the development of the regulatory state: he was able to witness the enormous challenges it posed for institutional design in government. Even so, he says almost nothing about how regulations should be formulated, justified, or "overseen" in a democratic state, or about how regulatory institutions can be fair and efficient given the omnipresent potential to be corrupted by the very firms they regulate and the politicians who oversee them. Some of this "corruption" could be dealt with in ways he actually mentions_-public financing of elections, free access to major media for candidates, campaign spending limits, and the like. But even good Rawlsian citizens (the kind who pursue their own interests but also have a sense of justice and are loyal to just institutions, as long as they think others are) can have their judgment influenced by conflicts of interest, regulatory "capture," and revolving-door career paths.

iii. It is impossible to make the exploitation of all market failures illegal, and we don't need Lipsey and Lancaster (1956) to show us why it would be self-defeating to attempt to do so. Again, some market failures are deliberately created by regulation in order to deal with others. In many cases, the regulation and monitoring for a particular market failure would be 
much more expensive than the social cost of the market failure in question. Successful business strategy in highly competitive sectors will often have to operate as close as possible to the line of illegality. To survive in the market, firms will comply with the letter of the law, but not necessarily with its spirit. And so on. In short, there will always be a shortfall in the regulatory state (and sometimes an irrational overkill if regulators are too zealous). Profit-seeking firms in competitive markets can cause harm and injustice even while complying with all regulations. As Rawls himself notes, sometimes "the invisible hand guides things in the wrong direction." And, unfortunately, "there are no feasible and practicable rules that it is sensible to impose on individuals that can prevent the erosion of background justice" (Rawls 2003, 267).

iv. This suggests that it is not sufficient to assume, as Rawls does, that "individuals and associations [can be] left free to advance their ends more effectively within the framework of the basic structure" (Rawls 2003, 269) without their also having to follow (perhaps quite extensive) beyond-compliance norms of "responsible business." And among those norms, surely, must be the duty not to obstruct legitimate attempts to regulate their firm or industry, and perhaps even a positive duty for senior managers to help design socially responsible regulation that may not be in the interest of their owners or other key partners and stakeholders (Norman 2011; Heath 2014, 202). Once we decide, however, to go with a deliberately adversarial system rather than a hierarchically administered one, we cannot insist that the "players" should at all times act from "a sense of justice, the desire to act in accordance with the principles of justice that would be chosen in the original position" (Rawls 1999, 275). Managers cannot make strategic decisions based on what they think would be best for society; rather, they must act in accordance with the best interests of the business enterprise that employs them.

v. And then there is a major political consequence of life in the modern firm in volatile and competitive markets, where the object is to win, and where our understanding of human psychology would predict that a sense of entitlement to the spoils of winning will often be rationalized as a just reward. The corporate world is surely not the most ideal school for nurturing the sense of justice understood by Rawls. In all three of his books on justice as fairness, he has emphasized the following "feedback loop" that becomes especially pertinent for the design of deliberately adversarial institutions:

Everyone recognizes that the institutional form of society affects its members and determines in large part the kind of persons they want to be as well as the kind of persons they are. ... So an economic regime, say, is not only an institutional scheme for satisfying existing desires and aspirations but a way of fashioning desires and aspirations in the future. More generally, the basic structure shapes the way the social system produces and reproduces over time a certain form of culture shared by persons with certain conceptions of their good. (Rawls 2003, 269) 
In other words, we are never exactly taking "people as they are" in order to come up with "laws as they might be," as Rousseau would have it, because the laws change the people.

This is a special problem in deliberately adversarial institutions. Such institutions are designed to set up competitions where "players" play to win and benefit outsiders (society) primarily because a clever institutional design enables the invisible hand to do its magic by creating positive externalities in addition to mutually beneficial exchanges. But the culture and reinforced norms of those in the game may be-and are permitted by Rawls to be-very different from the culture and norms of a well-ordered society in Rawls's sense, just as the culture and internal norms of a religious organization can be very illiberal. We should expect the "players" in markets, with no ill intentions, will come naturally to believe that what they are doing is good for society, and to believe that the rather "Darwinian" norms of their game are, in fact, the legitimate norms of the society at large. The famous quote from the just-slightly-fictional character Gordon Gekko in the 1987 film Wall Street displays the inference, hidden by normal cognitive biases and rationalizations, that leads many successful people to believe:

that greed, for lack of a better word, is good. Greed is right, greed works. Greed clarifies, cuts through, and captures the essence of the evolutionary spirit. Greed, in all of its forms; greed for life, for money, for love, knowledge has marked the upward surge of mankind. And greed . . . will not only save Teldar Paper, but that other malfunctioning corporation called the USA. (Stone and Weiser 1987).

Of course, it doesn't have to be greed that a given successful person will credit as his or her driving motivation. It is, nevertheless, natural for people who have worked hard and plied their valuable skills to believe that (a) their success has been a benefit to society, as well, and (b) that they deserve and have earned the higher-than-average compensation they have received for this work. It is similarly common for highly successful people in all walks of life to feel, quite earnestly, that if others worked as hard as they have in pursuit of their dreams, these other people, too, could enjoy this kind of success. The upshot for egalitarians? This cocktail of normal cognitive biases, including the tendency to underestimate the role of good fortune in one's successes, could be expected to make the most successful and powerful people in the society inclined to support a more desert-based conception of justice, which places less emphasis on impartiality and equality.

So market economies are likely to "shape" not only the "kind of person" one is, or the "desires and aspirations" one has, as Rawls rightly anticipates, but also the conception of justice one is likely to favor. This is problematic for Rawlsians. A shared conception of justice is supposed to be the primary basis for social unity in a liberal state. Now, as Singer discusses at length in his article in this issue, Rawls expects his principles of justice to apply to the basic structure of major institutions in society; but these principles for the basic structure "do not apply directly to or regulate internally institutions and associations within society. Firms and labor unions, churches, universities, and the family are bound by constraints arising from the principles of justice, but these constraints arise indirectly 
from just background institutions" (Rawls 2001b, 10). In general, the aim is for "individuals and associations [to be] left free to advance their ends more effectively within the framework of the basic structure, secure in the knowledge that elsewhere in the social system the necessary corrections to preserve background justice are being made" (Rawls 2003, 268-69). In a few places, however, he raises an important caveat to this division of labor between, on the one hand, principles for the basic structure, and on the other, the rules for institutions and associations. And this is germane to both the "feedback loop" mentioned in paragraph (v.) above, and the moral psychology discussed subsequently. It is crucially important for Rawls's argument, which he makes clear in A Theory of Justice:

A just system must generate its own support. This means that it must be arranged so as to bring about in its members the corresponding sense of justice, and effective desire to act in accordance with its rules for reasons of justice. Thus the requirement of stability and the criterion of discouraging desires that conflict with the principles of justice put further constraints on institutions. They must be not only just, but framed so as to encourage the virtue of justice in those who take part in them. (Rawls 1999, 230-31)

And so, although the rules and norms in "local" associations like corporations or churches may diverge significantly from the two principles of justice, these associations are still expected to be governed in ways that help the whole system of institutions in the basic structure to track the demands of the principles of justice. "What we would like, of course, are just and effectively designed basic institutions that effectively encourage aims and interests necessary to sustain them" (Rawls 2003, 137). Or, put more strongly, "Defects in either kind of principle [i.e. for the basic structure or for "local" associations] can result in a serious failure of the conception of justice as a whole" (Rawls 2003, 54).

My attempt thus far in this article has been to sketch the nature of the formidable challenge that egalitarians like Rawls will face if they want to find a place for competitive markets with large business firms in a just political economy. Rawls himself is, of course, acutely aware of many aspects of the challenge. He repeats across all of his writings that one of the great dangers of the kinds of inequalities generated by markets, even those that might be justified by the difference principle, is that "those with greater wealth and position usually control political life and enact legislation and social policies that advance their interests" (Rawls 2003, 148, my italics). What I am suggesting is that a plausible understanding of human psychology would show that people who have become successful in the corporate world might very well advance their interests in the belief that the policies they are advocating are not merely in their interest, but also just. If the basic structure and the activities of people within firms and markets can shape their character and preferences, it can also shape their conception of justice. And if this happens, the system built on the initially more egalitarian conception of justice is likely to be unstable, especially given Rawls's oft-repeated and reasonable assumption that successful and wealthy individuals will have disproportionately more influence in politics. This is clearly a central challenge for any egalitarian seeking the value-generating properties of markets and efficiently governed business firms within their conceptions of a just society. 


\section{JUSTICE AS FAIRNESS AND POLITICAL ECONOMY}

To demonstrate how his theory of justice has some genuine bite, but also how it leaves open a number of debates on which we would need more empirical information, Rawls very quickly surveys what this theory would likely say about some of the most fundamental options in political economy. I have referred to a number of his arguments and claims already, but, in this section, I hope to be faithful to the coherent set of thoughts Rawls offers, quite concisely, on the implications of his theory of justice for what he saw as the classic questions of political economy in his day.

All of Rawls's basic options for political economy can, in fact, be seen as hinging on the choice of permissible governance structures for firms in the market. Rawls asks whether a just basic structure would permit or exclude (a) laissez-faire capitalism, (b) welfare-state capitalism, (c) property-owning democracy, (d) socialism with a command economy, or (e) liberal socialism with state-owned firms competing against each other in markets. As we have seen already, Rawls's arguments for and against these various options are examples of ideal-theory reasoning that might happen at various points in the "four-stage sequence" (Rawls 1999, 171-76). Again, his aim is less to develop a theory of political economy than it is to show how his principles can have powerful, concrete implications in the real world.

Rawls thinks that justice as fairness would not permit three of the five systems just mentioned. I will quote his rejections at length-in fact, nearly in their entirety - from the more developed discussion in his last book on the subject, Justice as Fairness: A Restatement (2001b), in part to show how cursory the argument is in his illustrative exercise. Laissez-faire capitalism would be judged incompatible with the principles because it "secures only formal equality and rejects both the fair value of the equal political liberties and fair equality of opportunity. It aims for economic efficiency and growth constrained only by a rather low social minimum" (2001b, 137). Welfare-state capitalism, he notes,

also rejects the fair value of the political liberties, and while it has some concern for equality of opportunity, the policies necessary to achieve that are not followed. It permits very large inequalities in the ownership of real property (productive assets and natural resources) so that control of the economy and much of political life rests in few hands. And although, as the name ... suggests, welfare provisions may be quite generous and guarantee a decent social minimum, covering the basic needs, a principle of reciprocity to regulate economic and social inequalities is not recognized. (2001b, 138)

It is worth noting how different in nature these kinds of claims are from some of the ones we discussed earlier about, for example, the way firms would act in a perfectly competitive market. Here, we seem to have empirical generalizations about actual political and economic phenomena, drawn from experiences of a few decades, mostly in the United States. They are not implausible claims. When there are great inequalities of wealth generated by a capitalist market economy, it is difficult to imagine that the wealthy will not find a way to dominate the political system and 
use it to sustain their advantages. Curiously, though, Rawls's subsequent discussion of his two favored systems does not involve support (let alone skepticism) from an appeal to a similarly realistic account of political and economic sociology.

The last of his rejected systems, state socialism with a command economy supervised by a one-party regime, barely gets to the starting gate for serious consideration. It would "violate the equal basic rights and liberties, not to mention the fair value of these liberties. A command economy is one that is guided by a general economic plan adopted from the center and makes relatively little use of democratic procedures or of markets (except as rationing devices)" (Rawls 2001b, 138).

This leaves two basic possibilities, neither of which has ever really been attempted anywhere in the world: so-called "liberal socialism," on the one hand, and property-owning democracy, on the other. Both would have multiparty, liberaldemocratic constitutions and competitive markets. In the former, the state would own all of the firms, including multiple firms competing in any given market; in the latter, "the background institutions [would] work to disperse the ownership of wealth and capital, and thus prevent a small part of society from controlling the economy, and indirectly, political life as well" (2001b, 139). Not much is said about how this dispersal of wealth and capital (which is privately owned) would happen in the property-owning democracy, apart from a vague suggestion that there would be "widespread ownership of productive assets and human capital (that is, education and trained skills) at the beginning of each period" (2001b, 139). ${ }^{21}$ And few details are given of the supposedly viable versions of liberal socialism, except that "economic power is dispersed among [state-owned] firms, as when, for example, a firm's direction and management is elected by, if not directly in the hands of, its own workforce" (2001b, 138). Presumably, the multiparty democracy would permit parties inimical to the economic model in place, but again, Rawls rarely considers the likelihood of basic disagreements about justice itself in the well-ordered state.

It is difficult to know what to make of this cursory case for these two options, and against welfare-state capitalism, although we must bear in mind that Rawls intended this to be merely an illustration of how to apply his principles of justice to very large-scale political and economic institutions. We might say, therefore, that what it reveals most clearly are Rawls's own hunches about 1) the remote possibility of egalitarian political and redistributive reform in capitalist welfare states, perhaps for reasons of the sort I sketched out earlier when discussing the moral psychology of the rich and powerful running large business enterprises in a competitive market system; and 2) how unproblematic it would be to get the economic benefits of a market economy with the latter two "unproven" options he discusses. With respect to the second point, he does not apply the same level of skepticism about the likelihood that those who fight within the system to gain economic and political power-whatever the system is-will not use that power to advance their own interests and to entrench their own dominance. And again, as we have seen, even when discussing capitalism, he barely considers at all the pivotal role of corporate finance and governance arrangements for firms in the overall efficiency of the markets in which these firms are the key players. 
So it should not be surprising that he doesn't really consider how inefficient the financing or governance of enterprises may well be within market socialism or property-owning democracy.

One of the most striking features of Rawls's arguments here is how they betray his egalitarian enthusiasm for the idea of workplace democracy. We find this across his major writings, and he sees it as a potential feature of both of these supposedly viable forms of political economy he endorses. Within these brief illustrative passages, the desirability of workplace democracy looks almost like an a priori inference from the nobleness of democracy to a very particular model of governance for real firms - this despite the fact that he is fully aware that the structure of his theory does not permit any direct inferences from the principles of justice for the basic structure as a whole to the internal rules for organizations and associations within that structure. The articles by Singer and Néron in this issue discuss at length the question of whether corporations are inside or outside the basic structure, and of what hangs on the answer to this question; I will not repeat their analyses here. Additionally, they both note Rawls's end-of-career discussion of worker democracy and how troubling it is for him and his project. In what follows, I will use this discussion primarily as a way to illustrate the importance of more informed reasoning about organizational governance, and what such informed reasoning might look like.

Rawls concludes this brief section on political economy by noting that "Mill's idea for worker-managed cooperative firms is fully compatible with propertyowning democracy, since such firms are not owned or controlled by the state" (2001b, 176). He then takes up this idea in the next section addressing Marx's critique of liberalism. Rawls would concede to Marx that there is a "major difficulty" for the institutions of property-owning democracy — namely, how they would consider "the importance of democracy in the workplace and in shaping the general course of the economy" (2001b, 178). He then turns to Mill's idea of worker-managed firms (1848/2006), noting: "Mill believed that people would prefer to work in such firms. . . . In due course these firms would increasingly win out over capitalist firms. A capitalist economy would gradually disappear and be peacefully replaced by worker-managed firms within a competitive economy" (2001b, 178). Rawls is clearly intrigued by this potential "third way" between socialism and capitalism. He is also troubled, though, because, in some straightforward sense, Mill was wrong: worker co-ops did not bury capitalism. Rawls then, rather uncharacteristically, asks six consecutive questions:

1. Was Mill "wrong about what people prefer," i.e., to work in worker-owned co-ops?

2. Or have such firms "not had a fair chance to establish themselves"?

3. "If the latter is the case, should such firms be granted subsidies, at least for a time, so that they can get going?"

4. "Would there be advantages from doing this that could be justified in terms of the political values expressed by justice as fairness, or by some other political conception of justice for a democratic regime?" 
5. "For example, would worker-managed firms be more likely to encourage the democratic political virtues needed for a constitutional regime to endure?

6. "If so, could greater democracy within capitalist firms achieve much the same result?"

Rawls not only fails to attempt to answer these questions but also confesses he has "no idea of the answers." "But certainly," he adds, they "call for careful examination. The long-run prospects for a just constitutional regime may depend on them" (all quotes, including those in the numbered list, from Rawls 2001b, 178-79).

\section{THEORIES OF THE FIRM TO THE RESCUE?}

Rawls is right about one thing: questions like those do call for careful consideration. And the prospects for a just constitutional regime, and certainly for a viable and just political economy, do depend on them (and other questions like them: by which I mean questions of firm governance and control such as the ones with which Singer begins his article in this issue). But the fact is, these questions have received careful attention, in numerous fields: from history and sociology to law and economics. The Nobel Prize in Economics was awarded to two pioneers in the development of theories of the firm: Ronald Coase in 1991 and Oliver E. Williamson in 2009. Coase is generally credited with launching the modern empirical theory of the firm: he opened up the "black box" of the firm to economists, who had generally treated "firms" and "households" as the basic units of analysis, by asking why firms should exist at all in a world in which workers may freely contract in the marketplace (Coase 1937). If markets are as efficient as economists and their libertarian enthusiasts proclaim, why would we want economic activity to take place in non-market, "authoritarian," command-and-control organizations? Coase's answer was that firms can reduce transaction costs, and this will often make them more efficient than an endless series of market contracts between individuals. The dominant theory of the firm for at least two decades now sees the firm as a so-called "nexus of contracts." It is often referred to as a "contractualist" theory of the firm because it models the firm as a set of voluntary contractual relations between individuals from the major "stakeholder" groups (employees, suppliers, customers, investors, lenders, etc). ${ }^{22}$ The firm is a "nexus of contracts" because it is the one common signatory to the contracts with all of these groups and individuals. For example, the owners of a corporation don't hire the workers or buy the supplies, the corporation does. And in the case of corporations and some other kinds of business firms, the firm owns all its stuff; it is not the property of the owners of the firm. This is, if you will, the essence of its legal fiction.

This law-and-economics approach should be of special interest to Rawlsians, not least because it operates at a useful level of abstraction from the world-though as an empirical theory it ultimately stands or falls on how well it explains and predicts trends in the real world of business. And as a normative theory for the grounding of corporate law (and the bodies of law chartering other kinds of business 
organizations), it incorporates both contractualist and efficiency considerations. The statutes and legal interpretations of corporate law are generally taken to be justified on the basis of their answers to two kinds of questions:

(a) what terms of governance would parties voluntarily contracting to form and finance a corporation agree to "were the costs of negotiating at arm's length for every contingency sufficiently low"? ${ }^{23}$ and (especially for a number of governance terms within corporate law that parties are not permitted to negotiate away from);

(b) what terms in corporate law will "advance the aggregate welfare of all who are affected by a firm's activities, including the firm's shareholders, employees, suppliers, and customers, as well as third parties such as local communities and the beneficiaries of the natural environment"? ${ }^{24}$

Much of this story about the theory of the firm and the grounding of corporate law is now familiar to business ethicists, but it is almost entirely absent from discussions of markets by political philosophers. Rawls never refers to this body of theory (even though he is open to many other branches of twentieth-century economics). But neither, for example, does John Tomasi in his important recent book Free Market Fairness (2012). As Néron notes in his article in this issue, Tomasi celebrates the forms of life available to individuals in the marketplace, but he tends to do so with examples involving small-business owners rather than, say, Wall Street financiers or the employees of large retail or fast-food corporations.

Returning to Rawls's questions about worker-management or worker-ownership, and about the organization of the economy within the basic structure, there are four points we can draw upon from debates over the theory of the firm. First, since the middle of the twentieth-century, all theorists of the firm would insist upon sharpening distinctions that Rawls seems to gloss over between worker democracy (e.g., through councils), worker management, worker oversight (e.g., with "co-determination" governance structures, where workers and owners both have a board of directors to oversee their interests), ${ }^{25}$ and worker ownership (or an employee cooperative or partnership). At least since the landmark publication of Adolf Berle and Gardiner Means's The Modern Corporation and Private Property in 1932, the primary challenge for theories of the firm and of corporate governance, and for the corporate law that is based on them, has been to cope with the separation of ownership and control. The nineteenth-century worries about powerful factory- and industry-owning barons managing their own empires had shifted to a worry about empire-building by a small clique of professional managers who truly controlled the large corporations that were now owned by a widely dispersed and uninformed mass of shareholders (see Chandler 1977). This separation of ownership and control remains the central agency problem at the heart of corporate governance. In many ways, agency problems are to the contractual relations within a firm what market failures are to transactions outside the firm. Agency problems can be just as pronounced for worker-controlled enterprises, which will also have to hire professional managers in any medium- or large-sized firm. Indeed, given the opportunity for managers to exploit the divergent interests 
of different kinds of employees, the implications of this problem are likely to be even more serious for worker-owned firms. There are also good reasons to think that the naive mismanagement of the "separation of ownership and control" provides the best explanation for the widespread failure of many state-owned enterprises to achieve their multiple objectives (including efficiency) in their heyday from the 1950s to the 1980s in the West, not to mention in the Eastern bloc (see Heath and Norman 2004). In short, from the mid-twentieth century on, the primary concern about justice and efficiency in the firm has shifted from the question of "who owns the means of production" to the problem of how to ensure that the actual managers of firms act in the interest of the firm and its principal stakeholders rather than merely in their own interest-or incompetently and in nobody's interest.

Rawls is committed to the belief that reasoning about the basic structure should be consistent with our best understanding of human behavior from the behavioral sciences. Agency issues, then, should be a problem for Rawlsians even from within ideal theory. We don't have to presume that managers will be corrupt (which would make it "merely" a noncompliance problem for non-ideal theory): we need only assume that, in the face of multiple goals and given the information asymmetries that make it difficult for boards or others to evaluate their performance, and taking into consideration the kinds of cognitive biases inherent in human psychology, even fairly dutiful managers will be prone to pursuing strategies that turn out to be in their individual interest more than they are in the interest of the firm or of society. In the case of workplace democracy, the manager's interests cannot be expected to coincide fully with the workers' interests. And in almost any large business operation, the interests of different kinds of workers are themselves heterogeneous and in conflict. It will be challenging for the workers' council to monitor and evaluate the professional managers, especially if managers are expected to satisfy multiple internal constituencies.

A second insight arising out of theories of the firm and corporate law over the past eighty years or so is that the notion of ownership or private property in the firm has evolved dramatically. In his consideration of possible systems of economic organization, Rawls continues to be concerned with the very nineteenth-century question of who owns the means of production. (Is it the state? Or a small group of private individuals? Or a widely dispersed group of individuals? Or workers?) But it is now clear in major Western economies that whoever "owns" the firm (or some portion of it), their rights of ownership can be so attenuated that it barely qualifies as a property right in any tangible sense. Equity investors are technically the owners of the modern corporation. But their right of ownership amounts merely to a right to vote for a slate of board members (a slate often proposed by management) in the hopes of getting a board that will be capable of overseeing managers and directing them to work in the investors' interests. ${ }^{26}$ The owners are said to have the right to residual earnings, if there are any, but in fact the board is free to decide to reinvest any profits. (Many profitable companies pay no dividends; Google, e.g., announces quite openly in its FAQ for investors that it has never paid a dividend and has no intention of doing so.) This sense 
of "ownership" is now so removed from a tangible form of property ownership that a majority shareholder of a modern corporation does not even have the legal right to step foot on company premises, let alone to help herself to a briefcase-full of office supplies or a free lunch at the office cafeteria. Of course, ownership of company stock, like any other form of paper security, is valuable, and it is often an investment that can grow in value. But when corporate law is determining the governance rights of "owners," it is no longer doing so as an extension of their property rights in any tangible way. The most profound innovation with the "public corporation" over previous forms of business organization is probably the concept of "limited liability," which "protects the assets of the firm's owners from the claims of the firm's creditors" (Armour, Hansmann, and Kraakman 2009, 10). Two individuals cannot contract privately to form a business that grants them this protection ("Let's you and I agree that if anybody sues this business we are creating, they will not be able to come after our private assets!"). Limited liability "has become a nearly universal feature of corporate law" around the world because it is deemed good for society, not simply for investors-because of the numerous ways it helps lower the costs of capital and promote aggregate social welfare (Armour, Hansmann, and Kraakman 2009, 9-11).

According to actual corporate law in most jurisdictions (such as Delaware, where most major U.S. corporations are chartered), and to the nexus-of-contracts theory of the firm that is trying to explicate it, the corporation itself owns its assets. The fiduciary duty of managers is to act in the interest of the firm, which is not always exactly the same as the interests of its nominal owners. Investors have, in effect, contracted with the firm for the right to control management and to claim the long-term residual earnings of the firm. But if the firm falls into potential insolvency, the investors will lose even these rights: creditors will take over control of the board, and current investors will have no say over any decision to dilute their shares to pennies-on-the-dollar in order to bring in new investors (see, e.g., Armour, Hertig, and Kanda 2009, 115-82; Ridley 2006, chap. 13).

A third insight from contemporary theories of the firm leads us more directly to the question both of Rawls's fondness for Mill's dream of a marketplace dominated by worker co-ops, and his worries about why this has not come to pass. ${ }^{27}$ Rawls asked two questions: first, whether Mill was wrong in assuming that workers prefer to work in worker-owned co-ops; and second, whether such firms had not had a fair chance to establish themselves. The answers to these questions are, yes, workers in most settings will not prefer to work in large worker-owned firms, let alone to start one and grow it; and no, it does not seem to be the case that this form of firm is treated unfairly in the system. On the contrary, at least in North America, co-ops enjoy a distinct tax advantage, since member disbursements or "profits" redistributed back to the owners (the workers of a worker co-op) are not subject to double taxation the way corporate profits and dividends are. Another observation worth highlighting is that worker co-ops (or something similar such as professional partnerships) have, in fact, done well and even come to dominate in certain sectors, among them law firms, professional services and consulting, travel agencies, hedge funds, and, until recently, major investment banks. In fact, 
there are a number of sectors in which co-ops of one form or another have done well enough to dominate a sector (sometimes within a particular geographical region): much of the cheese in the United States comes from supplier co-ops; condominiums buildings are an example of tenant-owned co-ops, and often compete favorably against rental apartments; small, isolated prairie towns in Canada were often served by consumer co-op department stores; 70 percent of the population of the Canadian province of Quebec has an account in a co-op bank (or credit union/caisse populaire); MasterCard and Visa were both co-ops owned by two different consortia of banks until 2006 and 2008, respectively; some fast-food brands, or essential parts of their distribution functions, are owned by their franchisees; there are around 140 grower-owned co-ops in Champagne (the wine region of France) that produce the world's most famous bubbles; mutual insurance companies are owned by their policyholders; and so on. Co-ops do not dominate the economy, but given the right market conditions, they can dominate parts of it. And there are specific reasons why this should be the case.

The great insight of Yale legal theorist Henry Hansmann (1996) is that, from the point of view of the nexus-of-contract theory, most firms are essentially co-ops. The corporation is simply an investor co-op. We can translate the nineteenth-century problem of "who should own the means of production?" into "who should be in charge of the co-op?" And the short answer is, "whoever wants to be." In competitive markets, the firms with the most efficient form of "co-op ownership" should come to dominate the sector; in many sectors, however, firms with different ownership structures can coexist. The main stakeholder groups (Hansmann calls them "patron groups")—employees, suppliers, consumers, lenders, and investors - contract with the firm to pursue their individual interests. Most of these individuals and groups prefer to contract with the firm on relatively fixed terms, and, as long as the firm remains a going concern, they can expect to receive a fixed return. But in every co-op, one group will contract not for a guaranteed fixed return but for control of management and for a claim on residual earnings. This group will see a return on its investment (be it of capital, labor, supplies, or what have you) only if it is capable of solving the central agency problem and ensuring that management acts in the interest of the firm. If it can do this more effectively than other "patrons" can, then its costs of ownership will be lower than those of the others. And generally speaking, when this group does a good job of overseeing management, the other groups will likewise do well enough to want to continue their contractual relationship with the firm. ${ }^{28}$ An efficiently run firm provides benefits for its owners, but ownership also comes with substantial costs. And, perhaps most important, these costs will be significantly higher or lower for different "patron" groups in any given firm or sector.

In addition to the cost of agency problems, and of monitoring senior managers to control them, there are also substantial ownership costs of decision making. Democracy takes time, and time is, as they say, money. So why have investor-owned co-ops come to dominate most sectors in the modern economy? The answer is multifaceted, but much of the explanation comes from the fact that investors, 
by and large, have symmetrical interests: they all merely want to maximize (or at least satisfice) the expected return on their investment (Hansmann 1996, 53-88). ${ }^{29}$ This makes collective decision making easier and faster than it is for ownership groups that are more heterogeneous; and it makes it easier for them to set simple, measurable goals for management. Again, employee-owned firms have been quite successful in some sectors, like professional services; and part of the explanation for that is surely that there are not necessarily significant tensions or conflicts between the interests of the partners in a law or accounting firm. ${ }^{30}$ But in a large, hierarchical firm producing many product or service lines, and with many different kinds and grades of employees, there are significant conflicts between the interests and perceptions of employees (Hansmann 1996, 89-119). This will make their decision-making process more time-consuming, political, and prone to compromises that may resolve the standoff but will not serve the firm well in a competitive and rapidly evolving marketplace. It is also likely to lead to conservative strategic planning that favors current workers continuing to ply their old skills, rather than planning in ways that will anticipate emerging consumer demand or technological change. If IBM had been a worker co-op, it most certainly would have died along with the market for electric typewriters and mainframe computers. One might also note that worker co-ops cannot grow rapidly. Many tech start-ups begin as partnerships formed by a very small group of founders. But these individuals are typically happy (to say the least) to change the ownership structure and give up full control in exchange for the capital necessary to bring their innovation to market.

To sum up: this contractual framework that dominates contemporary theories of the firm should, in many ways, be congenial to Rawlsians. It assumes fair background conditions and asks how different parties would, if you will, choose to share the benefits and burdens of social cooperation within the firm and the marketplace. ${ }^{31}$ Of course, this contractualism is abstract relative to the market failures and unjust background conditions in the real world that make many actual choices (about issues such as where to work or what to buy) less than fully autonomous. But this kind of abstraction should not be problematic for Rawlsians. There is plenty of scope for the state to regulate the kinds of market failures in the real world that distort free and fair contracting in markets and to control for the abuse of power and information asymmetries within organizations. And, with this in hand, it is fairly easy to answer Rawls's first three questions about the promise (or lack thereof) of worker co-ops.

Workers do not in fact generally find it in their interest to assume the burdens and risks of ownership in return for residual earnings rather than a steady paycheck. ${ }^{32}$ There is no reason to blame this preference on unfairness in the system. If there is any unfairness, it is only that worker-owners will find it harder to get good terms of credit because they cannot post their own future labor as collateral. ${ }^{33}$ (It is not clear that permitting indentured servitude is a fair way to level the playing field!) And, of course, by definition, they cannot do what co-owners/workers do with start-ups-namely, sell a portion of control and rights to future revenues to investors in return for what is, in effect, an interest-free loan. Because at this point, 
the worker co-op would become a corporation! But given that worker-owners are free to seek this kind of investment rather than to rely on interest-bearing loans, it would seem that they, as individuals, are not being treated unfairly.

Rawls's three final questions ask whether worker democracy might be good for some other reasons, even if it is not preferred by workers themselves. A full answer to these questions would take us too far afield, but there are many things that could be said here. We might wonder whether lawyers and hedge-fund partners with lifelong experiences in something like "worker co-ops" are better democrats than others. We might question whether experience within worker councils would train citizens to be any more concerned with the general interest of society (as opposed to advancing their own group's legitimate interests) than participation in trade unions or on corporate boards of directors does. In any case, it surely cuts across the grain of Rawls's political liberalism to distort the basic structure in order to encourage a kind of firm ownership that is less efficient at producing wealth and that is not in the interests of any of the stakeholder groups voluntarily contracting with the firm (including, of course, consumers), just so that workers can be forced to practice their democratic virtues.

What I think the preceding sketch of governance relations within the firm should make plain is that we cannot think clearly about the choice of permissible institutions within the basic structure until we can open them up and evaluate the relations inside, so to speak. In other words, it is difficult to draw such a sharp line between the stages of theory construction (first domestic justice, then local justice), or the "division of labor between two sets of rules" for the basic structure and for organizations within it (Rawls 2003, 268), or between the institution and its members, or even between what is inside or outside the institution. As a nexus of contracts, the corporation is simply the legal fiction that contracts with all the other parties. There is no individual literally inside it; it has no spatial location, even though it might own or rent property. And employees who sell their labor to it (or invest their human capital in it) may have no more claim to being its "members" or "constituent parts" than the investors who provide its financial capital, or the suppliers who provide it with raw materials. ${ }^{34}$

\section{CONCLUSION}

I broadly support, and suspect that most egalitarians would support, Rawls's intuitions about the folly of applying fundamental principles of justice to the inner workings of all organizations or associations. You want efficiency and justice across the system, but you don't want to insist on every part of the system exemplifying those virtues, otherwise the system itself might end up less efficient and less just. But, in the twenty-first century, we can no longer talk about social justice without talking about markets (including capital markets and markets for corporate control); and we can't talk about markets seriously without talking about corporations (and other types of firms) and corporate governance; and we can't talk about those without theories of the firm, including theories that are more sociologically, culturally, and legally rich than the ones I have had space to sketch here. 
And finally we can't talk about sanctioning the use of private-sector firms in markets without thinking more seriously about the special nature of "deliberately adversarial institutions" and their regulation. Churches, universities, and families (to name the other institutions Rawls typically includes in the basic structure along with firms) are not deliberately adversarial institutions (though life within them is not always exactly friendly); but markets are deliberately adversarial, and the firms within them are the chief adversaries.

As noted at the outset, the three articles in this special section of $B E Q$ have each been animated by similar concerns regarding the gap between theories of justice and theories of corporate governance, and by the surprising lack of apprehension about this gap that we find, particularly among political philosophers. To the extent that these articles have succeeded, it is in showing how unjustified, or maybe embarrassing, this gap is, but also how challenging it will be for political philosophers to show how their theories of justice can be "applied" to these hitherto neglected questions and political economy in ways that could contribute to viable institutional designs or reforms. (Or in ways that match our "considered judgments," which are based on large bodies of research in the social sciences that political philosophers have largely ignored.) Both Singer and I have looked closely at different, but nonetheless overlapping, passages in the major writings of John Rawls, in large part because Rawls actually took these questions of political economy at the firm level more seriously than has tended to be the case in later and increasingly more abstract discussions of justice by luck egalitarians and public-reasons liberals.

Singer bravely argues for a null-hypothesis: he contends that there are central features of Rawls's theory that prevent it from grounding an adequate theory of corporate governance. The implications of my analysis of the many problems with Rawls's own attempts to frame and approach something like a theory of governance are less clear. I think Rawls was misled by the economics he read in his formative years, when the "black box" of the firm remained intact for most economists. But if Rawlsians open up that box now, and help themselves to useful tools and results from economics, law, and the behavioral sciences (as Rawlsians are always encouraged to do), then at the very least we can expect that they will be unlikely to arrive at all of Rawls's conclusions about political economy. Considerations of governance issues may dampen their receptiveness for socialist markets consisting of state-owned enterprises (even if run by their workers); and it should render them very skeptical about making any pronouncements on models of so-called property-owning democracy in the absence of very detailed proposals for the kinds of business charters that would be available in such an economy (i.e., the equivalent of corporate law) and the mechanisms for financing business ventures, among other things. It is also possible that Rawlsians, with some help from Henry Hansmann and especially Joseph Heath's "translation" of Hansmann for business ethicists and political philosophers, will come to accept the efficiency advantages of the "investor co-op" - especially in the context of a well-regulated market and a reoriented business culture that discourages the coercive exploitation of market failures. (This is what I referred to earlier as 
Heath's "bitter pill.") Rawls is willing to accept the difference principle ("social and economic inequalities are to be arranged so that they are ... to the greatest benefit of the least advantaged" [Rawls 1999, 266]) as a second-best ideal, because it is as a way to preserve egalitarian ideals in a world in which the direct pursuit of purely equal distributions would be self-defeating. Similarly, Heath argues, Rawlsians should accept something like Pareto efficiency as a third-best principle of justice for markets, because the difference-principle would be "subject to insurmountable difficulties at the level of implementation" (Heath 2014, 181).

Although Rawlsians and other egalitarians might be led to this place, they may remain distinctly uncomfortable about how, exactly, they are to reconcile the demands of efficient markets dominated by large, efficiently managed corporations on the one hand, with the basket of egalitarian ideals listed in Rawls's two famous principle of justice on the other. ${ }^{35}$ These firms will generate great inequalities of wealth; it is not at all clear that governments can rectify these through, say, taxation; and this is true, in part, for reasons that Rawls saw clearly-namely, because the best-off are likely to mobilize politically to limit tax policies that are not in their interest. It may be worse than this for Rawlsians and many other liberal egalitarians. I have argued here that even Rawlsians have grounds to be skeptical that an egalitarian democracy with large corporations and adversarial markets will "form" citizens with the desires, virtues, and conceptions of justice needed to provide the political will that is so crucial to the stability of institutions grounded in Rawlsian ideals. The kicker for Rawlsians is that if the institutions cannot shape citizens with the sense of justice to sustain them, it doesn't necessarily follow that those institutions have to be changed. It may be that the conception of justice that grounded those institutions has to be rejected or significantly revised (for reasons based on the "strains of commitment" that the parties in the original position have already used to reject principles of utilitarianism, perfectionism, and pure egalitarianism).

Even if Singer overstates the case that there can be no Rawlsian theory of corporate governance, ${ }^{36}$ it remains an open possibility that no adequate theory of political economy or corporate governance can be Rawlsian in the good old-fashioned sense. These are the major challenges for political philosophers in this tradition who are committed to the development of egalitarian theories of justice that can help us make sense of the most powerful economic institutions our civilization has ever known.

\section{ACKNOWLEDGMENTS}

I have profited from questions, criticisms, and suggestions by students and colleagues when I presented earlier versions of this paper at the Canadian Political Science Association meetings and at the Center for Law and Philosophy at the University of Arizona. I am particularly grateful for discussions and correspondence on these topics with Jacob Levy, Daniel Weinstock, Pierre-Yves Néron, Dominic Martin, Peter Dietsch, Chris MacDonald, Emily White, Jeff Moriarty, Sareh Pouryousefi, Thomas Christiano, Simone Sepe, Allen Buchanan, Amy Sepinwall, Alan Strudler, Carson Young, Matthew Lister, Eric Orts, Abe Singer, David Rönnegard, and Waheed 
Hussain. Special thanks to John Boatright, who introduced a generation of political philosophers in business ethics to theories of the firm and to the work of Henry Hansmann; and to Denis Arnold for surgical editing and a vast reservoir of patience. Most of the questions, models, and ideas in this paper arose over almost a decade of talking and cowriting with, not to mention reading, Joe Heath. It is entirely possible that there are unacknowledged arguments here that were his before they were mine, but I surely own any mistakes that appear in this article.

\section{NOTES}

1. For early explorations of this neglect, see Denis Thompson (2005) and Allen Buchanan (1996).

2. "Justice as fairness" is the name Rawls gives to his own conception of justice. The discussions of Rawls in all three of the articles in this special section of $B E Q$ presume a certain familiarity with the most well-known features of his theory of justice, especially as it is outlined in the first chapter of $A$ Theory of Justice. Explanations will be provided for concepts and arguments in Rawls's work that don't come into play until later in that book or in his subsequent publications.

3. Singer (2015, p. 68). In the opening section of his article in this issue Singer provides an excellent survey of the many different attempts to ground mid-level theories-mostly from business ethics and theories of corporate social responsibility — on more abstract theories of justice. The survey includes some political theorists moving in the other direction, most notably David Ciepley, whose American Political Science Review article "Beyond Public and Private: Toward a Political Theory of the Corporation" (2013) is something of a game changer. Ciepley is not writing as a liberal-egalitarian theorist, however, and cites no major political philosophers from that tradition, not even Rawls.

4. Other oft-cited notable figures in moral and political philosophy, as well as related social sciences, include Immanuel Kant (198 times), Milton Friedman (192-mostly for a single but lengthy New York Times Magazine article, it must be said!), Thomas Hobbes (95), Lawrence Kohlberg (82), Karl Marx (80), Robert Nozick and Jürgen Habermas (both at 68), Carol Gilligan (46), Friedrich Hayek (29), and Ronald Coase (27). I am grateful to Carson Young for his extensive mining of the data on Rawls and other topics in $B E Q$. He used Google Scholar to identify relevant articles and dedicated considerable time to a thorough, old-fashioned reading of the articles to distinguish between passing references to, and detailed relevant discussions of, Rawls's work in the journal.

5. The primary reference to property-owning democracy in Rawlsian scholarship until 2012 was Krouse and McPherson (1988).

6. An encouraging trend in recent egalitarian theory exploits the kaleidoscope of real-world markets to distinguish some generally legitimate markets from a number of potentially problematic ones, such as sexual labor, surrogate motherhood services, or organ sales, which are then explored in much more detail. See, e.g., Phillips (2013), Satz (2010), Grant (2012), and Sandel (2013), along with Néron's (2015) discussion of these texts and the relational approach to justice in the work of Elizabeth Anderson (see, e.g., Anderson 1995). For a forthcoming response to these critiques of particular markets, see Brennan and Jaworski (2015).

7. The Federal Register records all proposed and final rules and regulations, as well as notices of upcoming regulatory processes and executive orders set forth by the U.S. federal government. In 2013, a year many will remember as one of extreme gridlock in Congress, the Federal Register was 80,462 pages long. It would take four years for one very diligent congressional staffer working eight hours a day, seven days a week, to merely read a single year's edition of the Federal Register. And this obviously does not include consideration of state or municipal regulations, let alone taking time to reflect on the merits of any of the regulatory reforms or proposals described. For similar illustrations of the scope of the regulatory state, see Dudley and Brito (2012).

8. For notable exceptions, see Richardson (2002) and Arnold (2009). Also see the works of Cass Sunstein from both before and especially after his stint as President Obama's "regulation czar," i.e., Sunstein (2013) and (2014).

9. Corporate law, which is the legal background framework for corporate governance, concerns itself with relationships to groups other than stockholders, including employees and creditors. (See, e.g., Kraakman et al. 2009, chaps. 4-6.) 
10. As should become clear when we discuss contemporary understandings of firms from law and economics, it is now generally unhelpful to hold onto the "folk" notion of a firm as having some kind of spatial location (like the factory in Charlie Chaplin's Modern Times) along with clearly defined groups of insiders or members, on the one hand, and outsiders contracting with the firm, on the other. Néron's article in this issue focuses on the egalitarian evaluation of relationships within a firm or between a firm and those, like consumers, who contract with it.

11. In other words, some kinds of business firms - say, corporations or partnerships or cooperativeswill be more efficient in particular markets and will tend to drive competitors of a different kind out of business. We will return to this issue in a discussion of Henry Hansmann (1996) later in this article.

12. The "constitutional convention" and "legislative stages," referred to just now are extensions of Rawls's famous "original position" argument. When it comes time to deciding which constitutional structures, and then which proposed pieces of legislation, would be just, the "veil of ignorance" is lifted slightly so that the parties from the original position can now know more about the actual society that they would be making these decisions for; though as in the original position, they would not know their place in the society. See Rawls 1999, chap. IV, sec. 31.

13. Singer argues that these limits on a political conception of justice ultimately constrain the ability of a Rawlsian theory of justice to be able to ground a theory of corporate governance (Singer 2015, pp. 81-86).

14. Another story about the same firm may have illustrated why, as a corporation, it had access to the capital necessary to purchase equipment that made it much more efficient-perhaps even much friendlier for the environment - than it could have done relying on the personal resources of the suppliers, had it been a supplier co-op instead.

15. For another random example, think of the unique opportunities for the managers and governmentappointed board members of state-owned enterprises to use their personal connections and mutual interests in rent-seeking interactions with regulators and politicians. See Heath and Norman (2004) for the governance lessons that advocates of CSR and "stakeholder management" can learn from the history of state-owned enterprises.

16. Both Singer and Néron discuss the interpretation and significance of the distinction between ideal and non-ideal theorizing in Rawls, and we will return to it in this article.

17. "Thus, the reason that 'society' favors competition in certain areas of life has everything to do with the [positive] externalities that are generated" (Heath 2014, 97). See also Martin (2013).

18. See Nancy Rosenblum's critique of the way parties have been "the orphans of political philosophy," even though they are "the darlings of political science" $(2008,3)$.

19. What Churchill actually said, in a speech to the House of Commons (11 November, 1947), is less cynical than the witty partial quote (which I have italicized in the passage below) that is often attributed to him: "No one pretends that democracy is perfect or all-wise. Indeed, it has been said that democracy is the worst form of Government except all those other forms that have been tried from time to time; but there is the broad feeling in our country that the people should rule, continuously rule, and that public opinion, expressed by all constitutional means, should shape, guide, and control the actions of Ministers who are their servants and not their masters." Published in The Official Report, House of Commons (5th Series), 11 November 1947, vol. 444: 206-7 (my italics).

20. For two very different preliminary sketches of the agenda of issues, see Applbaum (1999) and especially Heath (2006b; 2014).

21. Again, see Krouse and McPherson (1988), O’Neill (2008), and various chapters in O’Neill and Williamson (2012) for suggestions about institutional options for a Rawlsian property-owning democracy.

22. See Boatright (1996) and Norman (2010) for surveys of these theories of the firm and their relevance to major issues in business ethics and governance. Among the more influential major works in this tradition by lawyers and economists since Coase, especially in business ethics, are Williamson (1985), Alchian and Demsetz (1972), Jensen (2000), Easterbrook and Fischel (1991), and Hansmann (1996). For a departure from the strictly contractualist, law-and-economics approach in those texts, see, e.g., Blair and Stout (1999), Dow (2003), and Orts (2013).

23. Easterbrook and Fischel $(1991,15)$. Singer discusses the relation between this realm of contractualism (which sees corporate law as largely an "off-the-rack" contract that parties can also customize) and potential Rawlsian approaches to corporate law. 
24. Armour, Hansmann, and $\operatorname{Kraakman}(2009,28)$. Heath (2014, chap. 5) evaluates the fairness of this objective for corporate law.

25. See, e.g., Enriques, Hansmann, and Kraakman (2009).

26. They have a few other rights, e.g., to propose motions at the annual general meeting, motions that the board or managers are free to dismiss; to vote on major acquisitions or mergers, or on proposals to dissolve the corporation; and to sell their shares for whatever they can fetch on the open market.

27. See Hsieh (2005) for one of the most influential discussions in business ethics of these Rawlsian intuitions.

28. Once again, it should go without saying that, in the real world, all of these contractual relations are subject to market failures that may undermine the extent to which a given ownership structure for the firm will be in all stakeholders' mutual interest. See Heath (2014, chap. 5, 116-41) for both the most compelling and concise explanation of Hansmann's empirical theory, and an analysis of where it is most vulnerable when used to support normative claims about, say, Kaldor-Hicks efficiency.

29. See, e.g., Enriques, Hansmann, and Kraakman (2009, 89-99) for a survey of governance issues that arise when, say, the interests of minority and majority shareholders diverge.

30. It is noteworthy that not all employees in a law firm are owners-only the "partners" have an ownership stake. A large law firm in which the secretaries, security guards, paralegals, interns, junior attorneys, etc, were all equal partners would be unlikely to compete well against law firms operating with their typical governance structures.

31. At the point of contracting, these are, after all, simply market transactions of a sort we are presumably referring to when we are discussing the question of why markets are or are not justified. But once, say, an employment contract is signed and employees are brought into an organization, it makes sense (for reasons discussed by Néron) to treat the hierarchical and authority/subordinate relationships as more than a mere contractual relationship and as potentially subject to a variety of ethical norms, including norms derived from principles of equal moral worth. See also McMahon (1994; 2013) for extended discussions on the justification of authority within a corporation.

32. It is presumably rather common for employees in many lines of work to leave a company they have worked for and to start their own sole proprietorship to "work for themselves," or perhaps with a partner or two.

33. I probably owe this idea-along with so many others- to conversations with Joe Heath. See also Boatright (2004).

34. Compare two identical apartment buildings, side by side. One is owned by a corporation, which hires a management company to look after the place, and where tenants rent their units. The other is a condominium, a tenants' co-op, which hires the same management company to look after the place. We can understand why this kind of co-op thrives in a marketplace that includes corporations that rent apartments in part by asking ourselves this question: Who is in a better position to monitor the managers? Some corporate employees who live across town or across the country, or the tenants of the building? But my point here is, who is inside or outside of these two companies? Does our answer differ in the two cases, when the tenants go from being customers to being owners? Does it matter? Is it the employees in both buildings, like a doorman and superintendent, who are the ones "inside," while the tenants or unit owners are merely contracting?

35. For the final formulation of the two principles, see Rawls (1999, 266). We get a "basket of ideals" when we consider the many specific and basic civil, political, and religious rights and liberties, as well as the main "primary goods," that are referred to in that statement of the principles.

36. I have not given anything like a direct critique of Singer's main argument here.

\section{REFERENCES}

Alchian, Armen A., and Demsetz, Harold. 1972. "Production, Information Costs and Economic Organizations." American Economic Review 62(5): 777-95.

Anderson, Elizabeth. 1995. Value in Ethics and Economics. Cambridge, MA: Harvard University Press.

Applbaum, Arthur. 1999. Ethics for Adversaries. Princeton: Princeton University Press.

Armour, John, Hansmann, Henry, and Kraakman, Reiner. 2009. "What Is Corporate Law?"

In The Anatomy of Corporate Law: A Comparative and Functional Approach, 2nd ed., ed. Kraakman, Reiner et al., 1-34. Oxford: Oxford University Press. 
Armour, John, Hertig, G., and Kanda, H. 2009. "Transactions with Creditors.” In The Anatomy of Corporate Law, 2nd ed., ed. Kraakman, Reiner et al., 115-52. Oxford: Oxford University Press.

Arnold, Denis G. 2013. "Global Justice and International Business." Business Ethics Quarterly 23(1): 125-43.

Arnold, N. Scott. 2009. Imposing Values: An Essay on Liberalism and Regulation. Oxford: Oxford University Press.

Berle, Adolf A., and Means, Gardiner C. 1932/1991. The Modern Corporation and Private Property. Repr. New Brunswick, NJ: Transaction Publishers.

Blair, Margaret, and Stout, Lynn. 1999. "A Team Production Theory of Corporate Law." Virginia Law Review 85(2): 247-328.

Blanc, Sandrine, and Al-Amoudi, Ismael. 2013. "Corporate Institutions in a Weakened Welfare State: A Rawlsian Perspective.” Business Ethics Quarterly 23(4): 497-525.

Boatright, John. 1996. "Business Ethics and the Theory of the Firm." American Business Law Journal 34(2): 217-38.

. 2004. "Employee Governance and the Ownership of the Firm." Business Ethics Quarterly 14(1): 1-21.

Brennan, Jason, and Jaworski, Peter. 2016. Markets without Limits: Moral Virtues and Commercial Interests. New York: Routledge.

Buchanan, Allen. 1996. "Toward a Theory of Ethics of Bureaucratic Organizations." Business Ethics Quarterly 6(4): 419-40.

Chandler, Alfred D., Jr. 1977. The Visible Hand. Cambridge, MA: Belknap Press.

Child, James W., and Marcoux, Alexei M. 1999. "Freeman and Evan: Stakeholder Theory in the Original Position." Business Ethics Quarterly 9(2): 207-23.

Ciepley, David. 2013. "Beyond Public and Private: Toward a Political Theory of the Corporation." American Political Science Review 107(1): 139-58.

Coase, Ronald. 1937. "The Nature of the Firm." Economica 4(16): 386-405.

Dow, Gregory K. 2003. Governing the Firm: Workers' Control in Theory and Practice. New York: Cambridge University Press.

Dudley, Susan E., and Jerry, Brito. 2012. Regulation: A Primer. 2nd ed. Washington, D.C.: Mercatus Center at George Mason University.

Easterbrook, Frank H., and Fischel, Daniel R. 1991. The Economic Structure of Corporate Law. Cambridge: Harvard University Press.

Enriques, L., Hansmann, H., and Kraakman, R. 2009. "The Basic Governance Structure: Minority Shareholders and Non-Shareholder Constituencies." In The Anatomy of Corporate Law, 2nd ed., ed. Kraakman, Reiner et al., 89-114. Oxford: Oxford University Press.

Grant, Ruth. 2012. Strings Attached: Untangling the Ethics of Incentives. Princeton: Princeton University Press.

Hansmann, Henry. 1996. The Ownership of Enterprise. Cambridge, MA: Harvard University Press.

Hartman, Edwin. 2001. "Moral Philosophy, Political Philosophy, and Organizational Ethics: A Response to Phillips and Margolis.” Business Ethics Quarterly 11(4): 673-85.

Heath, Joseph. 2006a. "Business Ethics without Stakeholders." Business Ethics Quarterly 16(4): 533-57.

. 2006b. "An Adversarial Ethic for Business: Or When Sun-Tzu Met the Stakeholder." Journal of Business Ethics 72(4): 359-74. 
2014. Morality, Competition, and the Firm: The Market Failures Approach to Business Ethics. Oxford: Oxford University Press, 2014.

Heath, Joseph, Moriarty, Jeffrey, and Norman, Wayne. 2010. "Business Ethics and (or as) Political Philosophy.” Business Ethics Quarterly 20(3): 427-52.

Heath, Joseph, and Norman, Wayne. 2004. "Stakeholder Theory, Corporate Governance and Public Management: What Can the History of State-Run Enterprises Teach Us in the Post-Enron Era?" Journal of Business Ethics 53(3): 247-65.

Hsieh, Nien-hê. 2005. "Rawlsian Justice and Workplace Republicanism." Social Theory and Practice 31(1): 115-42.

Jensen, Michael. 2000. Theory of the Firm: Governance, Residual Claims, and Organizational Forms. Cambridge: Harvard University Press.

Kraakman, Reinier, Armour, John, Davies, Paul, Enriques, Luca, Hansmann, Henry B., Hertig, Gerard, Kopt, Klaus, Kanda, Hideki, and Rock, Edward, eds. 2009. The Anatomy of Corporate Law: A Comparative and Functional Approach. 2nd ed. Oxford: Oxford University Press.

Krouse, Richard, and McPherson, Michael. 1988. "Capitalism, 'Property-Owning Democracy,' and the Welfare State." In Democracy and the Welfare State, ed. Gutmann, Amy, 79-106. Princeton: Princeton University Press.

Lipsey, R. G., and Lancaster, Kelvin. 1956. "The General Theory of the Second Best." Review of Economic Studies 24(1): 11-32.

Mäkinen, Jukka, and Kourula, Arno. 2012. "Pluralism in Political Corporate Social Responsibility." Business Ethics Quarterly 22(4): 649-78.

Martin, Dominic. 2013. "The Contained-Rivalry Requirement and a 'Triple Feature' Program for Business Ethics.” Journal of Business Ethics 115(1): 167-82.

McMahon, Christopher. 1994. Authority and Democracy: A General Theory of Government and Management. Princeton: Princeton University Press.

. 2013. Public Capitalism. Philadelphia: University of Pennsylvania Press.

Mill, John Stuart. 1848/2006. Principles of Political Economy. In Collected Works of John Stuart Mill, vol. 3, ed. Bladen, V. W. and Robson, J. M. Indianapolis: Liberty Press.

Moriarty, Jeffrey. 2005. "On the Relevance of Political Philosophy to Business Ethics." Business Ethics Quarterly 15(3): 455-73.

Néron, Pierre-Yves. 2015. "Rethinking the Very Idea of Egalitarian Markets and Corporations.” Business Ethics Quarterly 25(1): 97-128.

Norman, Wayne. 2010. "The Financial Theory of the Firm." In Finance Ethics: Critical Issues in Theory and Practice, ed. Boatright, John, 143-59. Hoboken, NJ: John Wiley \& Sons.

. 2011. "Business Ethics as Self-Regulation.” Journal of Business Ethics 102(1): 43-57.

O'Neill, Martin. 2008. "Three Rawlsian Routes toward Economic Democracy." Revue de philosophie économique 8(2): 29-55.

O'Neill, Martin, and Williamson, Thad, eds. 2012. Property-Owning Democracy: Rawls and Beyond. Boston: Wiley-Blackwell.

Orts, Eric. 2013. Business Person: A Legal Theory of the Firm. Oxford: Oxford University Press.

Phillips, Anne. 2013. Our Bodies: Whose Property? Princeton: Princeton University Press. Phillips, Robert A., and Margolis, Joshua D. 1999. "Toward an Ethics of Organizations." Business Ethics Quarterly 9(4): 619-38.

Rawls, John. 1971. A Theory of Justice. Cambridge, MA: Belknap Press. 
1999. A Theory of Justice. Rev. ed. Cambridge, MA: Belknap Press. 2001a. The Law of Peoples. Cambridge, MA: Harvard University Press.

. 2001b. Justice as Fairness: A Restatement. Cambridge, MA: Harvard University Press.

2003. Political Liberalism. New York: Columbia University Press.

Richardson, H. 2002. Democratic Authority: Public Reasoning about the Ends of Policy.

New York: Oxford University Press.

Ridley, Ann. 2007. Company Law. 2nd ed. Abingdon, UK: Hachette Livre UK.

Rosenblum, Nancy. 2008. On the Side of the Angels: An Appreciation of Parties and Partisanship. Princeton: Princeton University Press.

Rousseau, Jean-Jacques. 1968. The Social Contract. Translated by Cranston, Maurice. Harmondsworth: Penguin.

Sandel, Michael J. 2013. What Money Can't Buy: The Moral Limits of Markets. New York: Farrar, Straus and Giroux.

Satz, Debra. 2010. Why Some Things Should Not Be for Sale: The Moral Limits of Markets. New York: Oxford University Press.

Singer, Abraham. 2015. "There Is No Rawlsian Theory of Corporate Governance." Business Ethics Quarterly 25(1): 69-96

Stone, Oliver, and Weiser, Stanley. 1987. Wall Street. Directed by Stone, Oliver. Los Angeles: Twentieth Century Fox Film Corporation.

Sunstein, Cass R. 2013. Simpler: The Future of Government. New York: Simon \& Schuster.

. 2014. Valuing Life: Humanizing the Regulatory State. Chicago: University of Chicago Press.

Toenjes, Richard H. 2002. "Why Be Moral in Business? A Rawlsian Approach to Moral Motivation.” Business Ethics Quarterly 12(1): 57-72.

Tomasi, John. 2012. Free Market Fairness. Princeton: Princeton University Press.

Whelan, Glen. 2012. "The Political Perspective on Corporate Social Responsibility: A Critical Agenda.” Business Ethics Quarterly 22(4): 709-37. 